\title{
Pollen studies in the genus Viola (Violaceae) from Iran
}

\author{
Shahryar Saeidi Mehrvarz ${ }^{1 *}$, NARJes Yousefi $^{1}$, MARYAm Mohammadi $^{1}$, \\ THOMAS MARCUSSEN ${ }^{2}$ \\ 1 Department of Biology, Faculty of Science, University of Guilan, P. O. Box \\ 41335-1914, Rasht, Iran. \\ ${ }^{2}$ Department of Plant and Environmental Sciences, University of Gothenburg, P. O. Box \\ 461, SE 40530 Gothenburg, Sweden.
}

\begin{abstract}
Pollen morphology of 17 species of Viola representing five sections, Melanium, Plagiostigma, 'Spathulidium' ined., Sclerosium, and Viola, was studied using light and scanning electron microscope. Pollen grains were usually symmetrical, tetrazonocolporate to pentazonocolporate in section Melanium and trizonocolporate to tetrazonocolporate in the other four sections. Pollen shape was circular to subtriangular, tetragonal or pentagonal in polar view and prolate to oblate, spheroidal or pyramidal in equatorial view. Exine ornamentation was granulate, psilate and mostly perforate. The psilate type was only observed in $V$. modesta. We found heteromorphy in aperture number in $V$. caspia of section Viola, V. occulta of section Melanium and V. behboudiana of section Sclerosium, which corroborates their higher ploidy than in related species (octoploid versus tetraploid).
\end{abstract}

Key words: Exine, morphology, ornamentation, palynology, pollen, Viola

\section{Introduction}

Viola L. is the largest genus of Violaceae, with ca 600 species and is the only one widely distributed in the Northern Hemisphere (BALLARD et al. 1999). Infrageneric classification has varied, but recent phylogenetic analysis indicates that the genus can be subdivided into two subgenera and 16 sections worldwide (YOUSEFI et al. 2012). Five sections belonging to subgenus Viola are present in Iran: section Melanium Ging., section Plagiostigma Godr., section Viola, section Sclerosium W. Becker, and the undescribed section 'Spathulidium' ined. The three first sections are widespread in the Northern Hemisphere and together comprise a few hundred species, while the two last sections are restricted to parts of southwestern Asia with fewer than a dozen species. The sections are ancient allotetraploid except for section 'Spathulidium' which is inferred to be allooctoploid (MARCUSSEN et al. 2011). Recently, molecular phylogenetic analyses of sect. Melanium (including 25 species) were performed using ITS sequences and ISSR markers (YocKTENG et al. 2003); they have shown

\footnotetext{
* Corresponding author, e-mail: saeidimz@guilan.ac.ir

Copyright $^{\circledR} 2014$ by Acta Botanica Croatica, the Faculty of Science, University of Zagreb. All rights reserved.
} 
that sect. Melanium forms a derived and monophyletic group. Section Melanium, the pansies, is represented in Iran by five annual-ephemeral species, V. arvensis, V. kitaibeliana, $V$. modesta, V. occulta, and V. tricolor. The only species of section Plagiostigma occurring in Iran, V. somchetica, belongs to subsect. Patellares (Boiss.) Rouy and Foucaud. Section Viola is restricted to northernmost Iran, where it occurs with six species, V.alba (subsp. alba), $V$. odorata, and $V$. sintenisii in subsect. Viola and V. caspia, V. reichenbachiana, and $V$. rupestris in subsect. Rostratae. Section Sclerosium is distributed in the South of Iran with three putative species, V. behboudiana, V. cinerea and V. stocksii. Section 'Spathulidium' ined. refers to a small group of three central Asian species, in Iran represented by $V$. spathulata and V. pachyrrhiza; V. maymanica occurs in northern Afghanistan (SCHMIDT 1992). 17 species of Viola are distributed in different parts of Iran, mainly in the north. Of these, only $V$. spathulata is endemic to the territory (Elbrus mountains), but another five species are endemic to the region.

The delimitation of Viola species within sections and subsections can be problematic in many regions of the world, owing partly to phenotypic plasticity, partly to hybridisation and polyploidy, and partly to the few morphological characters separating taxa. Introgression appears, however, to be rare and restricted to certain groups (VALENTINE 1962, KRAHULKOVÁ et al. 1996, MARCUSSEN et al. 2001, HiLDEBRANDT et al. 2006).

Pollen morphology of Violaceae in general has been examined by some authors (ERdtMan 1952, PetTet 1964, Walker and Doyle 1975). A few additional studies have been published on pollen morphology in Viola. GoRB (1994) studied 12 Ukrainian species of Viola sect. Melanium (including V. arvensis, V. kitaibeliana, and V. tricolor) using both light and scanning electron microscopy. PERVEEN and QAISER (2009) examined five Viola species (including V. stocksii) from Pakistan. Dinç (2009) studied two species of subsection Viola (V. sandrasea, V. kizildaghensis) endemic to Turkey. Pollen heteromorphism is defined as the production by the same plant of pollen grains differing in aperture number (TILl-BotTRAud et al. 1995). This phenomenon occurs in over $30 \%$ of angiosperm species (Mignot 1994). In Viola pollen heteromorphism occurs in about a third of the studied species and appears to be associated with polyploidy (NADOT et al. 2000).

The main aim of this study is to provide a descriptive investigation of pollen grains in the genus Viola and also of pollen heteromorphism in the species distributed in Iran, using light and scanning electron microscopy. In light of the nomenclatural confusion and paucity of morphological characters for discrimination of Viola taxa in Iran (YousEFI et al. 2012), pollen morphology and heteromorphism may provide new characters useful for the delimitation of these taxa. In this study, pollen morphology of 13 species of the genus Viola with the exception of V. arvensis, V. kitaibeliana, V. tricolor and V. stocksii are described for the first time.

\section{Material and methods}

Pollen of 24 taxa representing the 17 species of Viola occurring in Iran was studied by means of light microscopy (LM) and scanning electron microscopy (SEM). Pollen samples were obtained from herbarium specimens collected the same year. In order to ensure the constancy of pollen characters among different populations of a certain species, 2-3 specimens per population were included in the analysis; otherwise each species was represented by only one population. The voucher specimens were deposited in Guilan University Her- 
barium. A list of the voucher specimens is given in table 1. Pollen grains were stained with basic-fuchsine, then mounted in glycerin jelly and prepared for LM observation. Some measurements i.e. polar axis $(\mathrm{P})$, equatorial axis $(\mathrm{E})$, colpus length and exine thickness were made by LM (Nikon microscope model Optiphot-Z optic) for 30 pollen grains under a magnification of 1000x. For analysing pollen heteromorphism, the number of apertures were counted for 100 pollen grains, then the percentage of each aperture-class -three, four and five- were calculated and the percentage lower than 95 was reported as heteromorphic pollen (MignOT 1994).

For SEM observations, pollen grains soaked in absolute ethanol were pipetted directly on to $12.5 \mathrm{~mm}$ diameter stubs and air-dried at room temperature; they were then coated in a sputter coater with approximately $25 \mathrm{~nm}$ of Gold-Palladium. The micrographs were ob-

Tab. 1. Collection data of Viola species examined in the present. Species endemic to Iran are indicated by an asterisk $(*)$.

\begin{tabular}{|c|c|c|}
\hline Species & Sect. / Subsect. & Collection data \\
\hline $\begin{array}{l}\text { V. arvensis } \\
\text { Murray }\end{array}$ & Melanium Ging. & $\begin{array}{l}\text { Iran: Mazandaran, Javaherdeh, Jirkoh, May 1999, } \\
\text { Naderifar, GUH-13682 }\end{array}$ \\
\hline $\begin{array}{l}\text { V. kitaibeliana } \\
\text { Schult. }\end{array}$ & & $\begin{array}{l}\text { Iran: Mazandaran, East slope of Damavand, above } \\
\text { Malar, June 2000, Moosavi \& Mozafarian, TARI-33184 }\end{array}$ \\
\hline $\begin{array}{l}\text { V. modesta } \\
\text { Fenzl }\end{array}$ & & $\begin{array}{l}\text { Iran: Kohgiluye-Boyer Ahmad, Nourabad to Yasuj road, } \\
30 \mathrm{~km} \text { to Yasuj, May 2009, Yousefi, GUH-13263-1 }\end{array}$ \\
\hline V. occulta Lehm. & & $\begin{array}{l}\text { Iran: Guilan, Deylaman, May 2009, Yousefi \& Saeidi, } \\
\text { GUH-13683 }\end{array}$ \\
\hline V. tricolor $\mathrm{L}$. & & $\begin{array}{l}\text { Iran: Guilan, Rudbar, April 2009, Ghahremani, } \\
\text { GUH-13663 }\end{array}$ \\
\hline $\begin{array}{l}\text { V. somchetica } \\
\text { C. Koch }\end{array}$ & $\begin{array}{l}\text { Plagiostigma Godr./ } \\
\text { Estolonosae Kupffer }\end{array}$ & $\begin{array}{l}\text { Iran: Ardebil, Almas road, April 2009, Yousefi \& Shahi, } \\
\text { GUH-13674 }\end{array}$ \\
\hline $\begin{array}{l}\text { V. behboudiana } \\
\text { Rech. F. et Esfand. }\end{array}$ & Sclerosium & $\begin{array}{l}\text { Iran: Baluchestan, Hudar, Ghasre ghand, } 380 \mathrm{~m} \text {, } \\
\text { Foroughi, TARI-10755 }\end{array}$ \\
\hline $\begin{array}{l}\text { V. cinerae } \\
\text { Boiss. }\end{array}$ & & $\begin{array}{l}\text { Iran: Bushehr, 2-3 km of NE Khormoj, } 150 \mathrm{~m} \text {, } \\
\text { Mozafarian, TARI- } 17141\end{array}$ \\
\hline $\begin{array}{l}\text { V. stocksii } \\
\text { Boiss. }\end{array}$ & & $\begin{array}{l}\text { Iran: Hormozgan, Bandar-Abas, } 20-30 \mathrm{~km} \text { of W Rudan, } \\
200 \text { m, Wendelbo \& Foroughi, TARI-15630 }\end{array}$ \\
\hline $\begin{array}{l}\text { V. spathulata } \\
\text { Willd.* }\end{array}$ & «Spathulidium « ined. & $\begin{array}{l}\text { Iran: Mazandaran, Chalous-Karaj road, Duzdbon, April } \\
\text { 1977, Ghahreman \& Aghoostin, TUH-11252 }\end{array}$ \\
\hline $\begin{array}{l}\text { V. pachyrrhiza } \\
\text { Boiss. et Hohen. }\end{array}$ & & $\begin{array}{l}\text { Iran: Lorestan, Aligudarz road to Shoolabad, } 2400 \text { m, } \\
\text { Runemark \& Lazari, TARI-26228 }\end{array}$ \\
\hline $\begin{array}{l}\text { V. caspia (Rupr.) } \\
\text { Freyn } 1\end{array}$ & $\begin{array}{l}\text { Viola/Rostratae } \\
\text { (Kupffer) W. Becker }\end{array}$ & $\begin{array}{l}\text { Iran, Guilan,, Lahijan, Sheitan koh, March 2008, } \\
\text { Tabarestani, GUH-13634 }\end{array}$ \\
\hline $\begin{array}{l}\text { V. caspia (Rupr.) } \\
\text { Freyn } 2\end{array}$ & & Iran: Guilan, Masouleh, Yousefi, GUH-4369 \\
\hline $\begin{array}{l}\text { V. caspia (Rupr.) } \\
\text { Freyn } 3\end{array}$ & & $\begin{array}{l}\text { Iran: Guilan, Lahijan, Sheitan koh, March 2007, Yousefi, } \\
\text { GUH-13681 }\end{array}$ \\
\hline $\begin{array}{l}\text { V. reichenbachiana } \\
\text { Jord. ex Bor. }\end{array}$ & & $\begin{array}{l}\text { Iran, Guilan, Asalem to Khalkhal road, March 2009, } \\
\text { Yousefi \& Asaadi, GUH-13651 }\end{array}$ \\
\hline
\end{tabular}


Tab. 1. - continued

\begin{tabular}{|c|c|c|}
\hline Species & Sect. / Subsect. & Collection data \\
\hline $\begin{array}{l}\text { V. rupestris F. W. } \\
\text { Schmidt }\end{array}$ & & $\begin{array}{l}\text { Iran: Ardebil, Almas road, April 2009, Yousefi \& } \\
\text { Asaadi, GUH-13672 }\end{array}$ \\
\hline $\begin{array}{l}\text { V. alba } \text { Bess. } \\
\text { subsp. alba } 1\end{array}$ & Viola/Viola & $\begin{array}{l}\text { Iran: Guilan, Masouleh, March 2008, Royan, } \\
\text { GUH-13266 }\end{array}$ \\
\hline $\begin{array}{l}\text { V. alba } \text { Bess. } \\
\text { subsp. alba } 2\end{array}$ & & $\begin{array}{l}\text { Iran: Guilan, Tootkabun, April 2009, Yousefi \& Saeidi, } \\
\text { GUH-13684 }\end{array}$ \\
\hline $\begin{array}{l}\text { V. alba } \text { Bess. } \\
\text { subsp. alba } 3\end{array}$ & & $\begin{array}{l}\text { Iran: Guilan, Lahijan, Sheitan koh, 2008, Yousefi, GUH- } \\
13271\end{array}$ \\
\hline V. odorata L. 1 & & $\begin{array}{l}\text { Iran: Guilan, mountains of Masouleh, March 2008, } \\
\text { Yousefi \& Saeidi, GUH-13665 }\end{array}$ \\
\hline V. odorata L. 2 & & $\begin{array}{l}\text { Iran: Guilan, Masouleh road, March 2007, Yousefi \& } \\
\text { Saeidi, GUH-13481-2 }\end{array}$ \\
\hline $\begin{array}{l}\text { V. sintenisii } \mathrm{W} \text {. } \\
\text { Becker } 1\end{array}$ & & $\begin{array}{l}\text { Iran: Guilan, Lahijan, Sheitan koh, February 2008, } \\
\text { Yousefi, GUH-13675 }\end{array}$ \\
\hline $\begin{array}{l}\text { V. sintenisii } \mathrm{W} \text {. } \\
\text { Becker2 }\end{array}$ & & $\begin{array}{l}\text { Iran: Guilan, Lakan, February 2008, Yousefi, } \\
\text { GUH-13281 }\end{array}$ \\
\hline $\begin{array}{l}\text { V. sintenisii W. } \\
\text { Becker } 3\end{array}$ & & Iran: Guilan, Lashtenesha, the rice field, GUH-13296-2 \\
\hline
\end{tabular}

tained from a LEO1430 VP(England) at an accelerating voltage of 10-15 kV under magnifications of $2040 \times$ to $11190 \times$. Pollen terminology according to WALKER and DOYLE (1975), PUNT (2007) and HALBRITTER et al. (2008) has been followed.

\section{Results}

\section{General pollen characters of the genus Viola}

The pollen grains were shed in monads, symmetrical, tetrazonocolporate to pentazonocolporate in section Melanium and trizonocolporate to tetrazonocolporate in the other four sections (Figs. 1-2, Tab. 2). The apertures were colporate, equatorially elongated and reached the poles of the pollen with rounded or acute ends.

The smallest pollen grains belonged to $V$. spathulata $(\mathrm{P}=29 \mu \mathrm{m}, \mathrm{E}=26.08 \mu \mathrm{m})$ and the largest ones to $V$. arvensis $(\mathrm{P}=69.09 \mu \mathrm{m}, \mathrm{E}=68.23 \mu \mathrm{m})$. The $\mathrm{P} / \mathrm{E}$ ratio varied between 0.94 and 1.18 (Tab. 2). The exine thickness varied between $0.6 \mu \mathrm{m}$ (V. spathulata) and $1 \mu \mathrm{m}(V$. occulta).

Exine ornamentation proved to be a valuable taxonomic character in Viola. It varies from perforate, granulate, to psilate (Tab. 2). Among these patterns the simple psilate type represented by $V$. modesta is very characteristic.

\section{Section Melanium (Figs. 1A-G, 3A-G)}

Section Melanium is a morphologically well-defined group of about 125 species. Of these, five species are distributed in Iran, mostly in the north. Members of this section have 


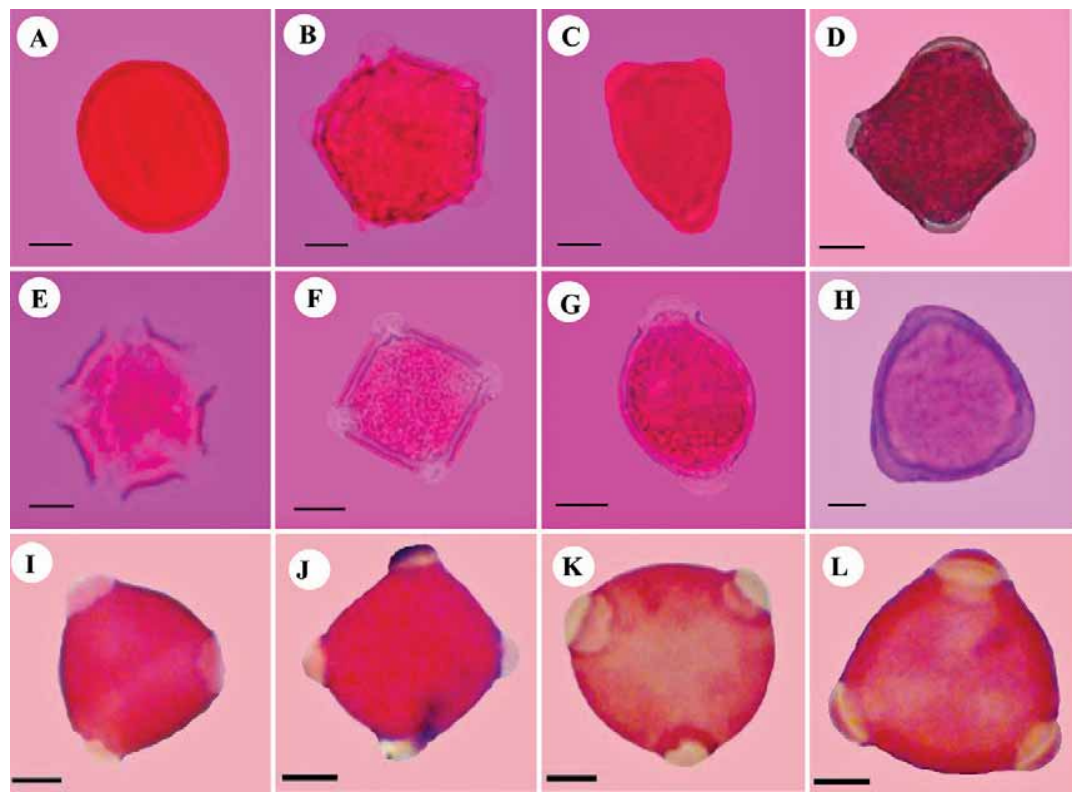

Fig. 1. Micrographs of pollen grains in Viola arvensis (A-B), V. kitaibeliana (C), V. modesta (D), V. occulta $(\mathrm{E})$, V. tricolor $(\mathrm{F}-\mathrm{G})$, V. somchetica $(\mathrm{H})$, V. behboudiana $(\mathrm{I}-\mathrm{J})$, V. cinerea $(\mathrm{K}), V$. stocksii $(\mathrm{L})$. Scale bar: $10 \mu \mathrm{m}$.

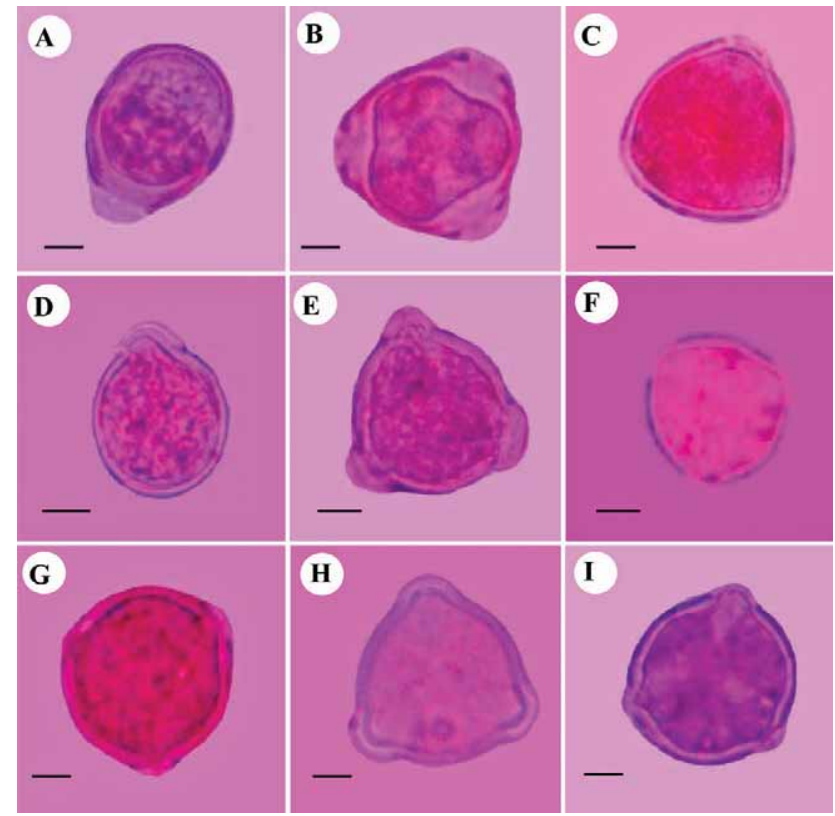

Fig. 2. Micrographs of pollen grains in Viola pachyrrhiza (A), V. spathulata (B), V. caspia (C), V. reichenbachiana (D-E), V. rupestris (F), V. alba (G), V. odorata $(\mathrm{H})$, V. sintenisii (I). Scale bar: $10 \mu \mathrm{m}$. 
Mehrvarz S. S., Yousefi N., Mohammadi M., Marcussen T.

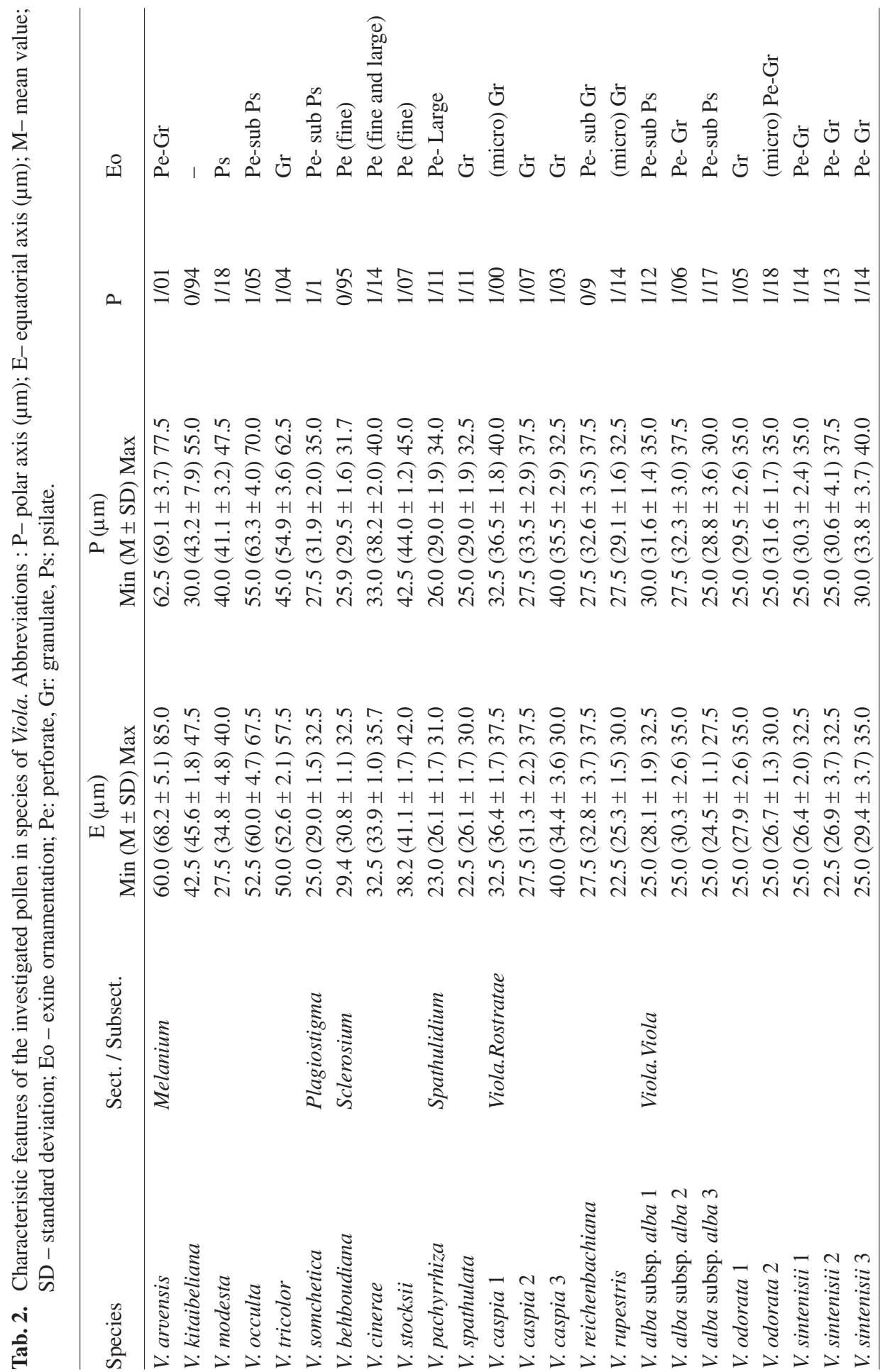


four to five apertures, while a more frequent aperture number in members of other sections is three. The pollen type of $V$. arvensis is perforate-granulate (Figs. 3A-B).

At species level, V. kitaibeliana with pyramidal shape in equatorial view (Fig. 1C) can be distinguished from the other species, which are prolate to spheroidal in shape.

Exine ornamentation does not provide valuable characters in delimitation of section Melanium from other sections, but it is useful for species recognition within this section. For instance, two morphologically close species, $V$. tricolor and $V$. modesta, have different types of exine sculpturing, i.e. granulate and psilate, respectively (Figs. 3C, F-G). Furthermore, $V$. arvensis, which exhibits a perforate to granulate exine, can be separated from its relative $V$. occulta, which has perforate to subpsilate exine (Figs. 3D-E).

\section{Section Plagiostigma (Figs. 1H, 3H-I)}

Viola somchetica is the only Iranian species of this section and its pollen grain in equatorial view and exine ornamentation is prolate-spherodial $($ Fig. $1 \mathrm{H})$ and perforate-subpsilate (Figs. 3H-I), respectively. From a palynological point of view, this species does not show any obvious morphological apomorphies.

\section{Section Sclerosium (Figs. 1I-L, 3J-L, 4A-C)}

Viola behboudiana is easily separated from the other Iranian species of the section by two palynological characters: the shape of pollen grains, which is oblate-spheroidal in $V$. behboudiana (Figs. 1I-J) and prolate-spheroidal in V. cinerea and V. stocksii (Figs. 1K-L),
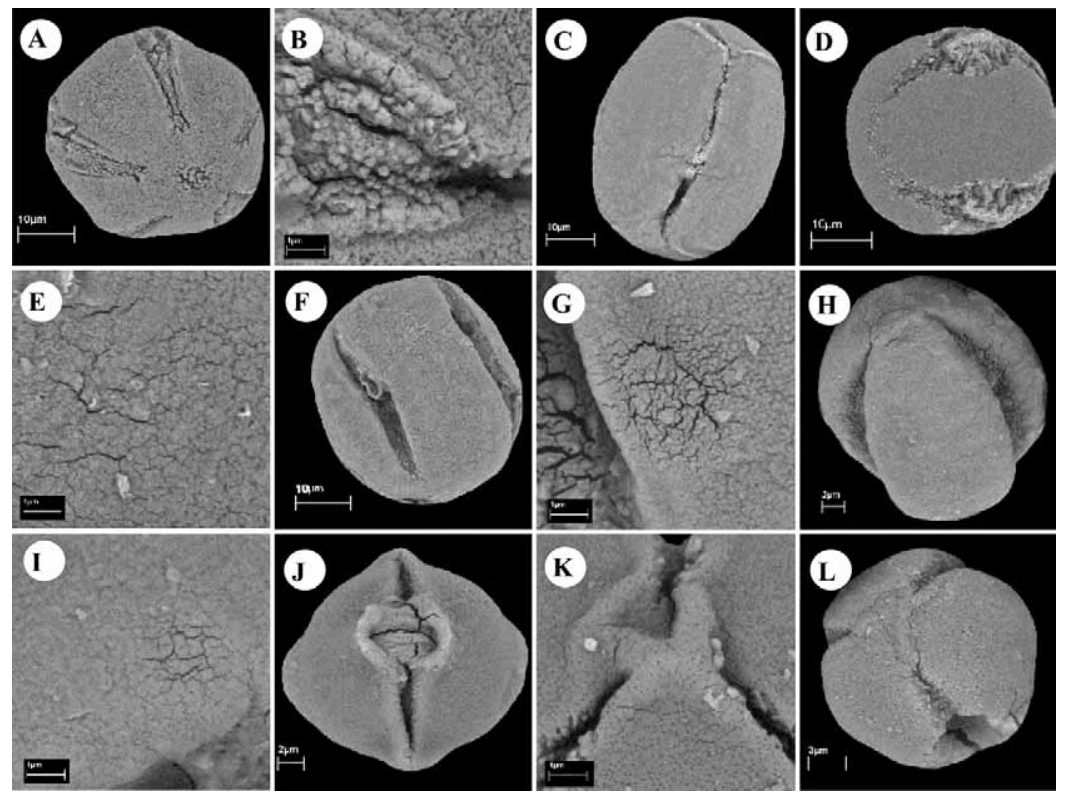

Fig. 3. SEM micrographs of pollen grains in Viola arvensis (A-B), V. modesta (C), V. occulta (D-E), V. tricolor $(\mathrm{F}-\mathrm{G})$, V. somchetica $(\mathrm{H}-\mathrm{I})$, V. behboudiana $(\mathrm{J}-\mathrm{K})$, V. cinerea $(\mathrm{L})$. 
and the presence of pollen heteromorphism in V. behboudiana. All of the three species have perforate to perforate-subpsilate exine ornamentation (Figs. 3J-L, 4A-C).

\section{Section 'Spathulidium' ined. (Figs. 2A-B, 4D-F)}

The two Iranian species of Section Spathulidium are morphologically similar but can be easily separated using palynological characters: V. pachyrrhiza has perforate exine (Fig. 4D), whilst V. spathulata has granulate exine ornamentation (Figs. 4E-F). Pollen morphology shows a basic similarity between section Spathulidium and section Plagiostigma; however these two sections can be differentiated according to exine ornamentation (Tab. 2).

\section{Section Viola}

No palynological characters separate this section from the others.

\section{Subsection Rostratae (Figs. 2C-F, 4G-L, 5A)}

This subsection has three species in Iran, V. caspia, V. reichenbachiana and V. rupestris. The morphological recognition of the first two species is very problematic due to the variable morphological characters; however palynological studies provide useful characters for delimiting these taxa. Pollen grains of V. caspia are prolate-spheroidal to subprolate in equatorial view (Fig. 2C) with a granulate exine (Figs. 4G-J), while V. reichenbachiana has oblate-spheroidal pollen grains (Figs. 2D-E) with a perforate-subgranulate exine (Fig. $4 \mathrm{~K})$. Furthermore, V. caspia shows pollen heteromorphism, in which the dominant pollen shape has three apertures and $6 \%$ of pollen grains have four apertures. The characteristics of pollen sculpturing of $V$. rupestris are similar to V. caspia (Figs. 2F, 4L, 5A), but the P/E ratio of $V$. rupestris is larger than $V$. caspia (Tab. 2).

\section{Subsection Viola (Figs. 2G-I, 5B-I)}

This subsection has three species in Iran, V. alba, V. sintenisii, and V. odorata. Whereas the latter can be easily recognised using morphological characters, i.e. broad stipules and high number of leaf crenulae, the division between two first species is still problematic. The shape in equatorial view of three species is prolate-spheroidal to subprolate (Figs. 2G-I). Pollen characteristics are also variable between the taxa, particularly, the exine ornamentation shows that $V$. alba has perforate to subpsilate and perforate to granulate exine (Figs. 5B-C), V. sintenisii has perforate-granulate (Fig. 5H-I). Viola odorata has perforate to subpsilate and perforate to granulate exine (Figs. 5D-G).

\section{Discussion}

The exine sculpturing of the pollen grains, their size, shape and aperture numbers can be of taxonomic value in the studied taxa. The pollen size variability is a diagnostic value between some of the taxa within the same section, for example, between $V$. arvensis and $V$. kitaibeliana (sect. Melanium), V. modesta and V. occulta (sect. Melanium), V. cinerea and V. stocksii (sect. Sclerosium). 


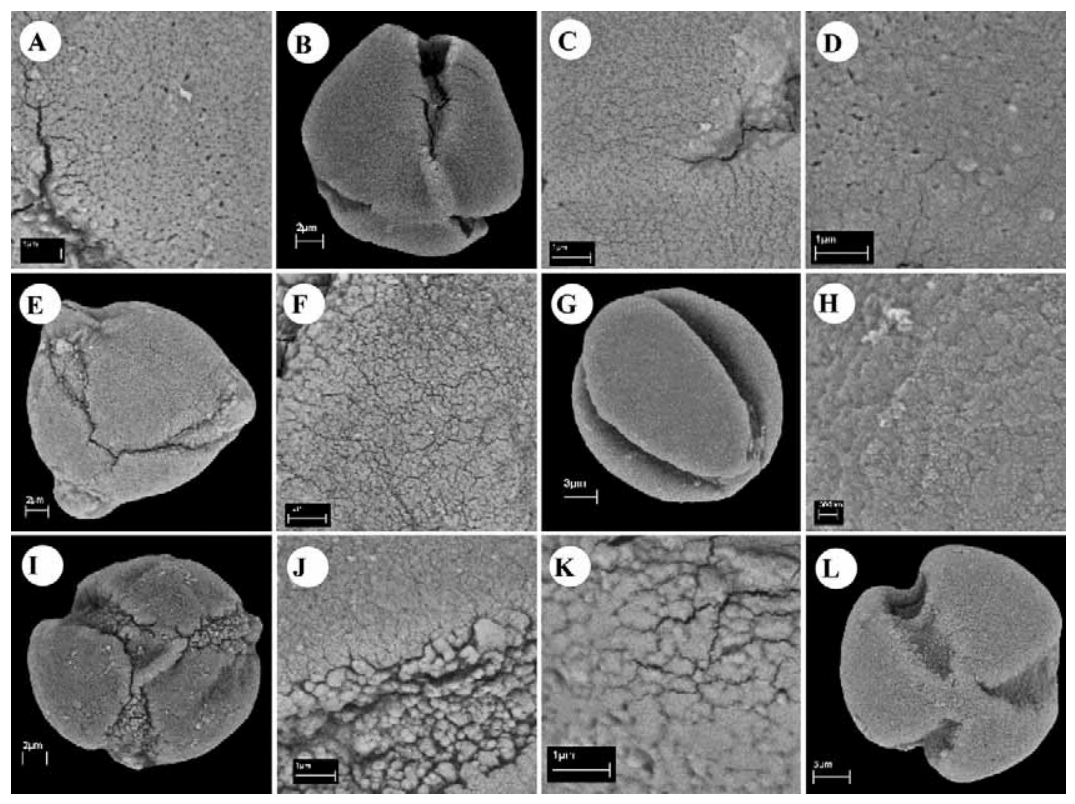

Fig. 4. SEM micrographs of pollen grains in Viola cinerea (A), V. stocksii (B-C), V. pachyrrhiza (D), V. spathulata $(\mathrm{E}-\mathrm{F})$, V. caspia $(\mathrm{G}-\mathrm{J})$, V. reichenbachiana $(\mathrm{K})$, V. rupestris $(\mathrm{L})$.

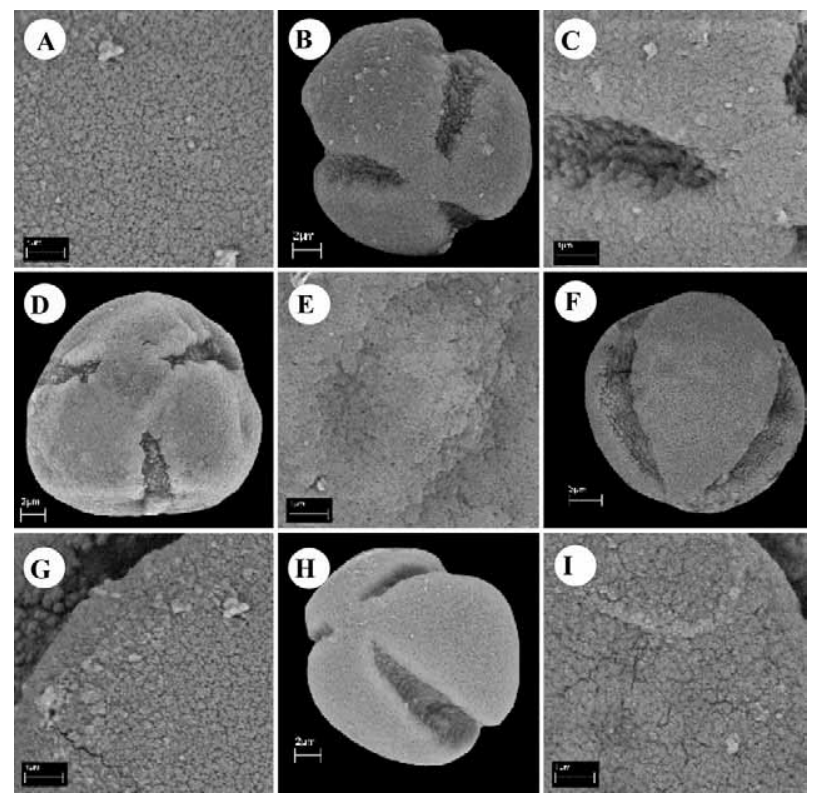

Fig. 5. SEM micrographs of pollen grains in Viola rupestris (A), V. alba (B-C), V. odorata (D-G), V. sintenisii $(\mathrm{H}-\mathrm{I})$. 


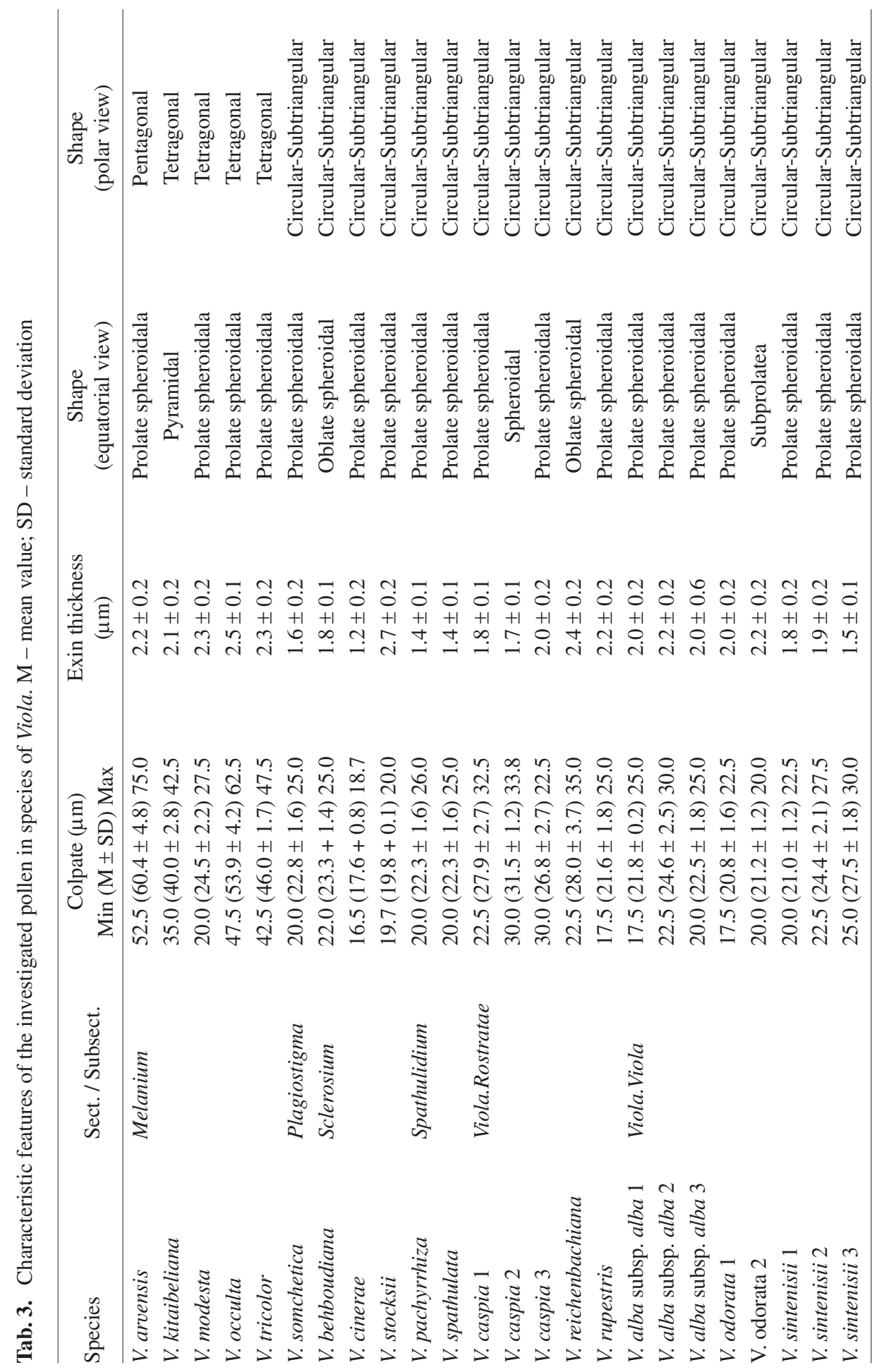


POLLEN STUDIES IN THE GENUS VIOLA (VIOLACEAE) FROM IRAN

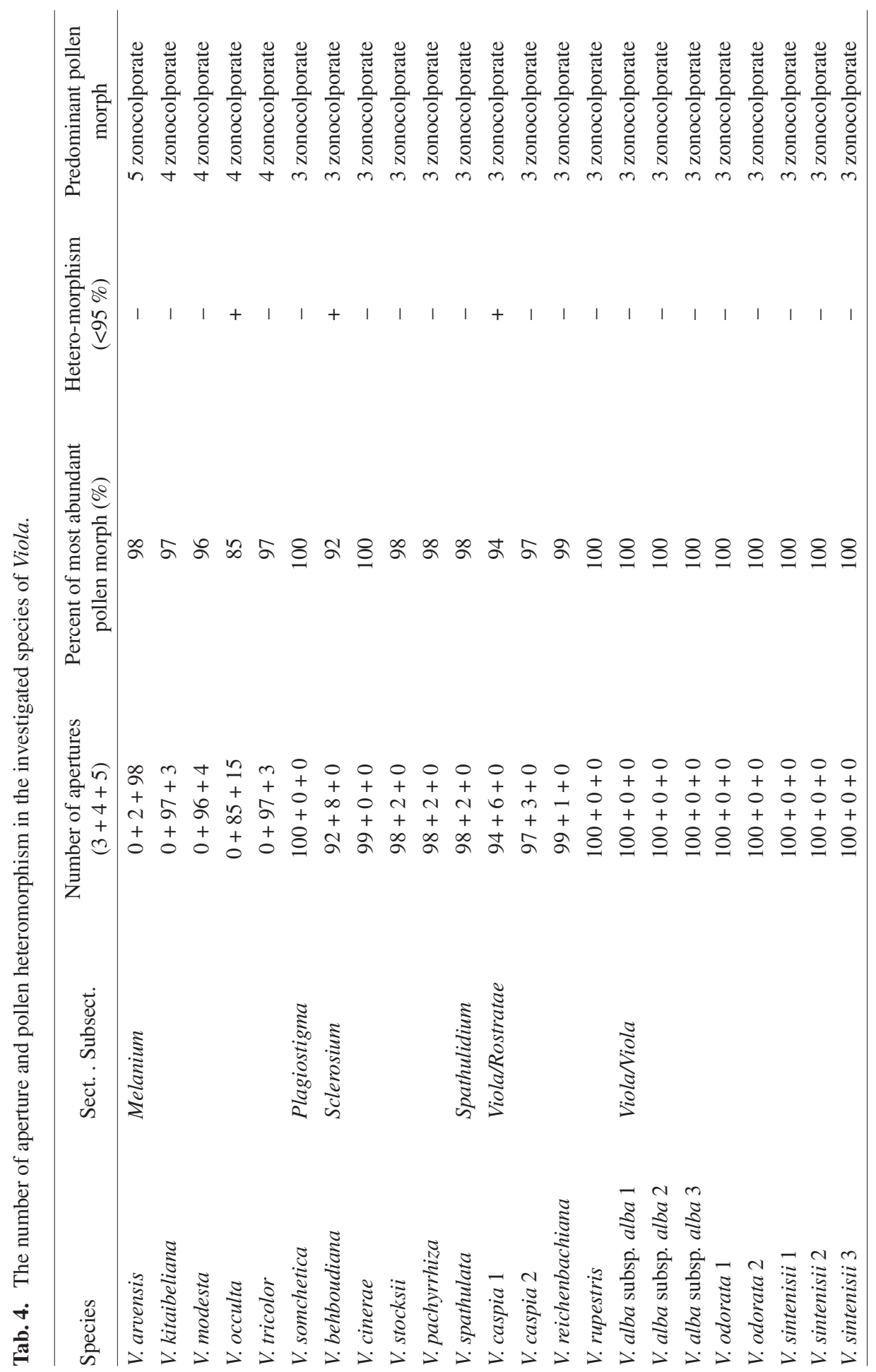


Pollen grains in polar view are variable within the sect. Melanium and the other sections (Tab. 2). A tetragonal to pentagonal shape in polar view is found in $V$. arvensis, V. kitaibeliana, V. modesta, V. occulta and V. tricolor (sect. Melanium), whilst circular-subtriangular is present in the other sections. The pollen shape of sect. Melanium was circular to sub-triangular, tetragonal or pentagonal in polar view and prolate to oblate, spheroidal or pyramidal in equatorial view according to the ratio of polar-equatorial axis (WALKER and DOYLE 1975).

According to the classification of pollen grains based on size (WALKER and DOYLE $1975)$, this section has large pollen grains $(50-99 \mu \mathrm{m})$, while the other sections of Viola distributed in Iran have medium sized pollen grains $(25-49 \mu \mathrm{m})$.

Pollen grains with six apertures were reported for $V$. arvensis from Ukraine (GoRB 1994). The figures given in ERDTMAN (1952) show that $V$. arvensis has 4-colpate with a few 5-colpate grains appearing to be based on misidentification with $V$. tricolor since this type is found in $V$. tricolor and not $V$. arvensis. PETTET (1964) noted that the two very variable and often confused species, $V$. tricolor and $V$. arvensis, are readily separable on the basis of pollen assemblage.

Earlier studies suggested that section Plagiostigma is not closely related to section Viola, as previously assumed (CLAUSEN 1929, MARCUSSEN et al. 2012). Our palynological results for Iranian $V$. stocksii agree with findings for this species in Pakistan (PERVEEN and QAISER 2009).

Previously these species, i.e.. V. pachyrrhiza and V. spathulata were included in section Plagiostigma subsection Patellares (as section Nomimium grex Adnatae; BECKER 1918). However, this lineage takes a completely different phylogenetic position and will require a section of its own (MARCUSSEN et al. 2010). Yousefi et al. (2012) demonstrated that Viola somchetica (section Plagiostigma) differs from V. spathulata (section Spathulidium) in the number of collenchyma layers at the corners of petiole cross sections (4 vs. 3) and the shape of peduncle cross sections (quadrangular $v$ s. circular).

Morphological and phylogenetic evidence supports two subsections, subsection Rostratae, with aerial floriferous stems and explosive capsules, and subsection Viola, lacking aerial stems and with inexplosive capsules (BECKER 1925, MARCUSSEN and KARLSSON 2010). Anatomically, V. caspia can be separated from V. reichenbachiana by the presence of a pith region in root cross-sections and by the number of vascular bundles in stem cross sections (YousEFI et al. 2012).

Viola behboudiana (section Sclerosium), V. caspia (section Viola) and V. occulta (section Melanium) showed structural polymorphism. The number of apertures in the two first ones was 3-4, and 4-5 in the last one. All three species are high-polyploids. Viola behboudiana and V. caspia are both octoploids (MARCUSSEN and BORGEN 2011), and this is probably the case also for $V$. occulta ( $n=10$ versus $n=3,4,5,7$ in its close tetraploid relatives; YocKTENG et al. 2003). In the genus Viola, pollen heteromorphism is a direct result of polyploidy (NADOT et al. 2000).

\section{Acknowledgements}

We thank to Mr. A. Khodayari (University of Ardebil) for his assistance in electron microscopy. This research was supported by a grant 989-27 from the research council of the University of Guilan. 


\section{References}

Ballard, H. E., Sytsma, K. J., Kowal, R. R., 1999: Shrinking the violets: phylogenetic relationships of infrageneric groups in Viola (Violaceae) based on internal transcribed spacer DNA sequences. Systematic Botany 23, 439-458.

BECKER, W., 1918: Violae Asiaticae et Australenses III. Beihefte zum Botanischen Centralblatt 36, 15-59.

BeCKer, W., 1925: Viola L. In: Engler, A. (ed.), Die natürlichen Pflanzenfamilien, 363376. Parietales und Opuntiales. Wilhelm Engelmann: Leipzig.

Clausen, J., 1929: Chromosome number and the relationship of some North American species of Viola. Annals of Botany 63, 741-764.

Dinç, M., 2009: Comparative morphological and palynological study on poorly known $\mathrm{Vi}$ ola sandrasea and its closest relative V. kizildaghensis. Biologia 64, 81-87.

ERdTMan, G., 1952: Pollen morphology and plant taxonomy: Angiosperms. Chronica Botanica Co., Waltham, Massachusettes.

GorB, O. V., 1994: Pollen morphology of section Melanium Ging. of genus Viola L. of Ukraine (in Ukrainian). Ukrainian Botanical Journal 51, 78-85.

Halbritter, H., Weber, M., Zetter, R., Frosch-Radivo, A., Buchner, R., Hesse, M., 2007: PalDat- Illustrated handbook on pollen terminology. Society of the Promotion of Palynological Research in Austria, Vienna.

Hildebrandt, U., Hoef-Emden, K., Backhausen, S., Bothe, H., Boźek, M., Siuta, A., KuTA, E., 2006: The rare, endemic zinc violets of central Europe originate from Viola lutea Huds. Plant Systematics and Evolution 257, 205-222.

KrahUlKovÁ, A., KRAHUleC, F., KIRSCHNER, J., 1996: Introgressive hybridization between a native and an introduced species: Viola lutea subsp. sudetica versus V. tricolor. Folia Geobotanica and Phytotaxonomica 31, 319-344.

Marcussen, T., Borgen, L., Nordal, I., 2001: Viola hirta (Violaceae) and its relatives in Norway. Nordic Journal of Botany 21, 5-17.

Marcussen, T., Karlsson, T., 2010: Violaceae. In: Karlsson, T. (ed.), Flora Nordica 6, 12-52. Swedish Royal Academy of Sciences, Stockholm.

Marcussen, T., Oxelman, B., Skog, A., Jakobsen, K. S., 2010: Evolution of plant RNA polymerase IV/V genes: evidence of subneofunctionalization of duplicated NRPD2/ NRPE2-like paralogs in Viola (Violaceae). BMC Evolutionary Biology 10, 45.

Marcussen, T., Borgen, L., 2011: Species delimitation in the Ponto-Caucasian Viola sieheana complex, based on evidence from allozymes, morphology, ploidy levels, and crossing experiments. Plant Systematics and Evolution 201, 183-196.

Marcussen, T., Blaxland, K., Windham, M. D., Haskins, K. E., Armstrong, F., 2011: Establishing the phylogenetic origin, history, and age of the narrow endemic Viola guadalupensis (Violaceae). American Journal of Botany 12, 1-11.

Marcussen, T., Jakobsen, K. S., Danihelka, J., Ballard, H. E., BlaXland, K., Brysting, A. K., OXELMAN, B., 2012: Inferring species networks from gene trees in high-polyploid North American and Hawaiian violets (Viola, Violaceae). Systematic Biology 61, 107-126. 
Mignot, A., Hoss, C., Dajoz, I., Leuret, C., Henry, J. P., Dreulllaux, J. M., Heberle-Bors, E., TILl-BotTRAud, I., 1994: Pollen aperture polymorphism in the angiosperms: importance, possible causes and consequences. Acta Botanica Gallica 141, 109-122.

Nadot, S., Ballard, H. E. Jr., Creach, J. B., Dajoz, I., 2000: The evolution of pollen heteromorphism in Viola: A phylogenetic approach. Plant Systematics and Evolution $223,155-171$.

Perveen, A., QAiser, M., 2009: Pollen flora of Pakistan, 61. Violaceae. Pakistan Journal of Botany 41, 1-5.

Pettet, A., 1964: Studies on British pansies I. chromosome numbers and pollen assemblages. Watsonia 6, 39-50.

Punt, W., Hoen, P. P., Blackmore, S., Nilson, S., Thomas, L., 2007: Glossary of palaeobotany and palynology. Review of Palaeobotany and Palynology 143, 1-81.

Schmidt, A. 1992: Violaceae. In: Rechinger, K. H. (ed.), Flora Iranica 169, 1-29. Akademische Druck- und Verlagsanstalt.

Till-Bottraud, I., Mignot, A., DE PAePe, R., Dajoz, I., 1995: Pollen heteromorphism in Nicotiana tabacum (Solanaceae). American Journal of Botany 82, 1040-1048.

VAlentine, D. H., 1962: Variation and evolution in the genus Viola. Preslia 34, 190-206.

WALKER, J. W., DoYle, J. A., 1975: The bases of angiosperm phylogeny: Palynology. Annals of the Missouri Botanical Garden 62, 664-723.

Yockteng, R., Ballard, H. E., Mansion, G., Dajoz, I., Nadot, S., 2003: Relationships among pansies (Viola section Melanium) investigated using ITS and ISSR markers. Plant Systematics and Evolution 241, 153-170.

Yousefi, N., Saeidi Mehrvarz, S., Marcussen, T., 2012: Anatomical studies on selected species of Viola (Violaceae). Nordic Journal of Botany 30, 461-469. 